\title{
Temperature-dependent metabolism in Antarctic fish: Do habitat temperature conditions affect thermal tolerance ranges?
}

\author{
Tina Sandersfeld ${ }^{1,2,3} \cdot$ Felix C. Mark $^{1}$ - Rainer Knust ${ }^{1}$
}

Received: 17 April 2015/Revised: 16 March 2016/Accepted: 16 March 2016/Published online: 12 April 2016

(C) The Author(s) 2016. This article is published with open access at Springerlink.com

\begin{abstract}
Climatic warming is most pronounced in the polar regions. For marine ectotherms such as fish, temperature is a key abiotic factor, influencing metabolic processes. Species distribution and abundance are driven by reproduction and growth, which depend on available energy exceeding baseline maintenance costs. These routine metabolic costs make up a large part of the energy expenditure. Thermal stress can increase routine metabolism, affecting an organism's fitness. Data of routine metabolic rates of Antarctic fish are scarce, and comparability of existing data sets is often problematic due to ecological differences between species and in experimental protocols. Our objective was to compare routine metabolism and thermal sensitivity of species with similar ecotypes but different thermal environments to assess possible ecological implications of warming waters on energy expenditure in Antarctic fish, a fauna characterised by geographic isolation, endemism and putative thermal adaptation. We measured routine metabolic rates of three benthic Antarctic fish species from low- and high-Antarctic
\end{abstract}

Electronic supplementary material The online version of this article (doi:10.1007/s00300-016-1934-x) contains supplementary material, which is available to authorized users.

Tina Sandersfeld

tina.sandersfeld@uni-hamburg.de

1 Helmholtz Center for Polar and Marine Research, Alfred Wegener Institute, Am Alten Hafen 26, 27568 Bremerhaven, Germany

2 Department of Marine Zoology, BreMarE - Bremen Marine Ecology, FB 2, University of Bremen, Leobener Str. NW2, 28359 Bremen, Germany

3 Present Address: Institute for Hydrobiology and Fisheries Science, University of Hamburg, Olbersweg 24, 22767 Hamburg, Germany regions at habitat temperature and during acute temperature increase. Our analysis revealed differences in metabolic rates at the same temperature suggesting local adaptation to habitat temperature. Acute thermal stress induced a comparable response of metabolic rates to increasing temperature. We conclude that higher metabolic rates and thus higher energetic costs could be associated with narrower thermal windows, a potential disadvantage to the endemic high-Antarctic fish fauna facing the challenge of climate change.

Keywords Routine metabolic rate - Polar fish .

Notothenioids $\cdot$ Metabolic cold adaptation $\cdot$ Respiration

\section{Introduction}

The polar regions comprise some of the "hot spots" of climatic warming. Around the Western Antarctic Peninsula, surface waters have risen in temperature about $1{ }^{\circ} \mathrm{C}$ in the second half of the twentieth century and around South Georgia a temperature increase of $2.3{ }^{\circ} \mathrm{C}$ has been recorded within the last 81 years (Meredith and King 2005; Whitehouse et al. 2008). Although temperature changes have not yet been recorded for high-Antarctic regions such as the Weddell Sea, water temperature increases of up to $2{ }^{\circ} \mathrm{C}$ have been projected by the year 2100 also for these areas (Hellmer et al. 2012; Turner et al. 2014).

Temperature is an abiotic key factor. In some ectotherms, such as many fish species, body temperature is determined by ambient temperature, affecting metabolic processes.

The thermal tolerance window of a species yields insight into physiological plasticity regarding changes in ambient temperature. According to the concept of oxygen and 
capacity limited thermal tolerance (OCLTT) (Pörtner 2012), the temperature window of an organism is defined by the upper and lower critical and pejus temperatures. At a species' optimal temperature, low maintenance costs and maximised aerobic scope were found to come along with high growth rates (Koehn and Shumway 1982; Wieser 1994; Brodte et al. 2006). Even though supporting evidence for the OCLTT concept was found in various species (Mark et al. 2002; Lannig et al. 2004; Pörtner et al. 2004), its general applicability and how to measure it has been still discussed in the recent literature (Clark et al. 2013; Norin et al. 2014).

Fish play an important role in Antarctic food webs. Being predator and prey alike, they serve as an important link between lower and higher trophic levels (Hureau 1994). The Southern Ocean has been an oceanographically isolated and thermally very stable environment over geological time scales, leading to the evolution of an endemic Antarctic fish fauna with highly stenothermal species. Antarctic fish exhibit different adaptations to their constantly cold environment, such as a lack of heat shock response, expression of anti-freeze glycoproteins, a lack of haemoglobin and myoglobin, higher mitochondrial densities as well as other compensatory adaptations of the heart and circulatory system (e.g. DeVries and Eastman 1981; Coppes Petricorena and Somero 2007). Compared to temperate species that experience broader environmental temperature fluctuations, Antarctic fish have very narrow temperature windows (Somero and DeVries 1967; Van Dijk et al. 1999; Brodte et al. 2006). However, habitat temperature does not only vary on global scales, but also within the Southern Ocean. In the lower, i.e. northern Antarctic region, shelf water temperatures are generally warmer (Barnes et al. 2006; Clarke et al. 2009), compared to the very stable high-Antarctic shelf region in the south with temperatures between -0.5 and $-1.9^{\circ} \mathrm{C}$ (Hunt et al. 2003). Evolution in these thermally different regions is likely to have affected thermal tolerance within Antarctic notothenioids. Studies on critical thermal maxima $\left(\mathrm{CT}_{\max }\right)$ showed thermal tolerance differences between high- and low-Antarctic species of up to $4{ }^{\circ} \mathrm{C}$ (Bilyk and DeVries 2011). Moreover, organismal freeze avoidance in Antarctic icefishes was shown to increase with distribution in increasing latitudes (Bilyk and DeVries 2010), indicating specific adaptation to the respective regional climate.

For a benthic marine fish species, Pörtner and Knust (2007) showed thermal limits determined in laboratory experiments to agree with ambient temperatures beyond which growth performance and abundance in the field declined. Growth and reproduction are the main driving forces for population dynamics and structure, thereby shaping a species' abundance and distribution (Pörtner and Knust 2007; Pörtner and Farrell 2008; Rijnsdorp et al. 2009).
However, growth and reproduction of an organism depend upon aerobic energy available after baseline costs of maintenance have been met (Koehn and Shumway 1982; Wieser 1994). Thus, knowledge on the impact of temperature on energy budget factors from experimental trials, such as routine metabolic costs, helps to estimate possible impacts of ocean warming on Antarctic fish. Routine metabolism measured in terms of oxygen consumption is an indirect measure of the energetic expenses necessary to keep an organism alive including processes such as protein synthesis or muscular activity, but can also include, e.g. energy allocated to spontaneous activity (Jobling 1994).

Various studies are available focusing on differences in routine metabolism and thermal tolerance between temperate, tropical and polar species (Johnston et al. 1991; Clarke and Johnston 1999; Vanella and Calvo 2005; White et al. 2012). However, data for Antarctic species are limited (Robinson 2008; Strobel et al. 2012; Enzor et al. 2013) and additionally comparability of single studies is complicated by differences in experimental set-ups, protocols and species' ecotypes, all of which have major effects on results (Chown et al. 2009; Bilyk and DeVries 2011). The aim of this study is to compare routine metabolism and thermal sensitivity of different Antarctic fish species from different thermal environments, i.e. low northern and high southern Antarctic regions, to gain insight in the impact of environmental temperature variability within Antarctic waters on a species' thermal tolerance. While a population's thermal tolerance is an important factor to assess, as it has direct fitness consequences in a warming Southern Ocean, ambiguities of species and regional effects cannot be resolved with this approach. In this study, we compare three notothenioid species from different latitudes, namely Lepidonotothen squamifrons, L. nudifrons and Trematomus hansoni, which are all benthic, shelf inhabiting species. While $L$. squamifrons displays a more northerly distribution around the sub-Antarctic islands, Bouvet Island and South Georgia, L. nudifrons inhabits the low-Antarctic waters of the Scotia Arc and the Antarctic Peninsula (Gon and Heemstra 1990). However, distributions of both species overlap around South Georgia. In contrast, T. hansoni has a circum-Antarctic distribution and also occurs in highAntarctic areas (Gon and Heemstra 1990).

We present a data set of routine metabolic rates at habitat temperature as well as in response to acute temperature increase of different Antarctic demersal fish species of similar ecotype measured with the same experimental set-up and protocol. Thereby, we want to approach the question how the geographically isolated and highly endemic Antarctic fish fauna will fare with progressing climate change and whether there will be differences in this putatively temperature sensitive species depending on habitat conditions. 


\section{Materials and methods}

\section{Animals}

In this study, the three Antarctic fish species, L. squamifrons, T. hansoni and L. nudifrons, were investigated. Locations of catch as well as habitat temperature variations for all species are shown in Table 1.

Lepidonotothen squamifrons were caught near South Georgia at a depth of $\sim 310 \mathrm{~m}$, water temperature of $2.1{ }^{\circ} \mathrm{C}$ and salinity of $34.4 \%$ by bottom trawl in March/ April 2011 (RV Polarstern, ANT-XXVII/3). Body weight of the fish ranged from 233.5-394.0 g $(287.21 \pm 19.57 \mathrm{~g}$, mean \pm standard error of the mean, $n=8$ ).

Trematomus hansoni were collected in the Eastern Weddell Sea at a depth of $\sim 225 \mathrm{~m}$, water temperature between -1.5 and $-1.9^{\circ} \mathrm{C}$, and salinity of $34.4 \%$ by bottom trawl in April 2011 (RV Polarstern, ANT-XXVII/ 3). Body weight of the animals was between 213.2 and $300.8 \mathrm{~g}(252.46 \pm 16.06 \mathrm{~g}, n=5)$. Experiments with $L$. squamifrons and $T$. hansoni were carried out after a recovery period of a minimum of 14 days on board $\mathrm{RV}$ Polarstern. During this time, $L$. squamifrons were kept at a temperature of $2{ }^{\circ} \mathrm{C}$ (habitat temperature measured before trawling), while $T$. hansoni were kept at the lowest technically possible temperature onboard the vessel of -0.5 to $0{ }^{\circ} \mathrm{C}$.

Lepidonotothen nudifrons were caught near Elephant Island at a depth of 70-322 m, water temperature of $0.0-0.8{ }^{\circ} \mathrm{C}$ and salinity of $34.2-34.5 \%$ by bottom trawl in March/April 2012 (RV Polarstern, ANT-XXVIII/4). Fish weight was $32.2-41.0 \mathrm{~g}(35.08 \pm 1.71 \mathrm{~g}, n=6)$. Animals were transported to the Alfred Wegener Institute in Bremerhaven (Germany) and kept in aquaria at $0-1{ }^{\circ} \mathrm{C}$. To minimise effects of captivity, fish were fed with krill (Euphausia pacifica) 1-2 times a week, as krill is an important prey for adult $L$. nudifrons in nature. Experiments were carried out in August 2012.
The temperature at which the animals were kept after being caught is here after referred to as habitat temperature and was used as the starting temperature for the respiration experiments. Experiments were stopped, when fish showed first signs of stress, indicated by a loss of balance and irregular movements of opercula.

\section{Oxygen consumption measurement}

Routine metabolic rates (RMR) in this study were measured by flow-through systems. Prior to each measurement oxygen probes were calibrated at the starting temperature for $100 \%$ oxygen saturation with air equilibrated seawater and for $0 \%$ saturation with nitrogen bubbled seawater. Before and after each measurement period, a blank, i.e. without an animal inside the respiration chamber, was measured to estimate bacterial respiration and fluctuation of the flow. Blank data showed negligible oxygen consumptions and therefore were not considered in calculations of oxygen consumption. Postprandial metabolism was reported to last between 3 and 13 days in Antarctic fish (Boyce and Clarke 1997; W. Davison personal communication). Thus, $L$. nudifrons was starved for a minimum of 10 days and $L$. squamifrons and T. hansoni for a minimum of 14 days prior to experiments, to exclude effects of specific dynamic action on metabolic rates. The fish were placed in the respiration chamber at habitat temperature. After a recovery period of at least $24 \mathrm{~h}$, oxygen consumption was measured for another $24 \mathrm{~h}$ at habitat temperature for RMR determination. Subsequently, temperature was increased by $1{ }^{\circ} \mathrm{C}$ per $24 \mathrm{~h}$. Temperature was continuously raised in the morning. In this way, settings could be supervised while temperature was increased and data for analysis were recorded at stable temperature overnight, as disturbance levels by surroundings were lowest during this time. A dimmed light was turned on all day long in the experimental room to display summer light conditions. In the beginning of each measurement, the flow rate was set in a way that the

Table 1 Location of catch (habitats), minimum and maximum habitat temperatures as well as time of experiment and time of spawning of species used in this study

\begin{tabular}{|c|c|c|c|c|c|c|c|}
\hline Species & Habitat & Latitude & Longitude & $\begin{array}{l}\text { Habitat } \\
\text { temp. } \\
\text { min. }\left[{ }^{\circ} \mathrm{C}\right]\end{array}$ & $\begin{array}{l}\text { Habitat } \\
\text { temp. } \\
\max .\left[{ }^{\circ} \mathrm{C}\right]\end{array}$ & $\begin{array}{l}\text { Time of } \\
\text { experiment }\end{array}$ & $\begin{array}{l}\text { Time of } \\
\text { spawning }\end{array}$ \\
\hline Trematomus hansoni & $\begin{array}{l}\text { Southern Ocean/ } \\
\text { Weddell Sea }\end{array}$ & $70^{\circ} 50^{\prime} \mathrm{S}$ & $10^{\circ} 36^{\prime} \mathrm{W}$ & -1.9 & -1.5 & April (autumn) & $\begin{array}{l}\text { February/ } \\
\text { March }\end{array}$ \\
\hline Lepidonotothen squamifrons & $\begin{array}{l}\text { Southern Ocean/ } \\
\text { South Georgia }\end{array}$ & $53^{\circ} 24^{\prime} \mathrm{S}$ & $42^{\circ} 40^{\prime} \mathrm{W}$ & 1.5 & 2.5 & $\begin{array}{l}\text { March/April } \\
\text { (spring) }\end{array}$ & February \\
\hline Lepidonotothen nudifrons & $\begin{array}{l}\text { Southern Ocean/ } \\
\text { Elephant Island }\end{array}$ & $61^{\circ} 01^{\prime} \mathrm{S}-62^{\circ} 29^{\prime} \mathrm{S}$ & $\begin{array}{r}54^{\circ} 40^{\prime} \mathrm{W}- \\
61^{\circ} 24^{\prime} \mathrm{W}\end{array}$ & -1.5 & 1.0 & August (winter) & April/May \\
\hline
\end{tabular}

Temperatures are derived from Ocean Data View data sets SOA and WOA09 (Olbers et al. 1992; Locarnini et al. 2010; Schlitzer 2011). Spawning times are derived from Sil'yanova (1982) and Andriashev (1986) 
out-flowing water displayed oxygen saturation between 95 and $90 \%$.

The term routine metabolic rates will be used in this study to describe oxygen consumption rates including all metabolic processes that contribute to keeping an organism alive (also often termed as basal or standard metabolism) plus spontaneous activity. Measured specimens were observed to adapt a tripod stance and showed very rare, but comparable spontaneous activity.

For calculation of metabolic rates, mean oxygen consumption of $8-12 \mathrm{~h}$ periods was used. For assessment of routine metabolic rates, at habitat temperature means were calculated over data of $24 \mathrm{~h}$ for L. nudifrons and T. hansoni, while $12 \mathrm{~h}$ intervals were used for L. squamifrons. Oxygen consumption rates were standardised by dividing them by body mass raised to the appropriate power for fish using a mass exponent of $b=0.818$ (Killen et al. 2007; postmetamorphic Myoxocephalus scorpius).

\section{Statistical analysis}

Statistical analysis was performed using $\mathrm{R}$ statistical language (R Core Team 2015; version 3.2.2). Only, data with more than 3 replicates per species were included in the statistical analysis. The significance level was set to $\alpha=0.05$ throughout the study. Data were checked for normal distribution (Shapiro-Wilk test, $p>0.05$ for all groups, removing one data point of L. squamifrons $\left(5^{\circ} \mathrm{C}\right)$ and $L$. nudifrons $\left(2^{\circ} \mathrm{C}\right)$, respectively, as outliers, one group was evaluated as false positive (L. squamifrons $3{ }^{\circ} \mathrm{C}$, $p=0.0373$ ) (see Online Resource 1-3, 5) and homogeneity of variances (Bartlett test, $p>0.05$ for each species). Logarithmic oxygen consumption data of single species in response to different temperatures were modelled linearly. Species-specific intercepts were tested for significant differences (ANOVA, common trend from linear model removed). Pairwise differences in intercepts were tested for significance by Tukey HSD (post hoc, $p<0.05$ for all species pairs).

\section{Results}

Oxygen consumption of L. squamifrons was highest at $2{ }^{\circ} \mathrm{C}$ with a value of $96.04 \pm 9.5 \mathrm{mg} \mathrm{O}_{2} \mathrm{~kg}^{-1} \mathrm{~h}^{-1}$. This is followed by $M_{\mathrm{O}_{2}}$ of $83.17 \pm 8.0 \mathrm{mg} \mathrm{O}_{2} \mathrm{~kg}^{-1} \mathrm{~h}^{-1}$ of $T$. hansoni at $0{ }^{\circ} \mathrm{C}$. Lowest oxygen consumption of $38.67 \pm$ $3.0 \mathrm{mg} \mathrm{O} \mathrm{kg}^{-1} \mathrm{~h}^{-1}$ was measured for L. nudifrons at $0^{\circ} \mathrm{C}$.

A linear fit revealed a significant effect of temperature on $M_{\mathrm{O}_{2}}(p<0.0001$, two-way ANOVA, no significant interaction), i.e. a significant increase of oxygen consumption with increasing temperature (see Fig. 1). With no significant differences in slopes (L. squamifrons/L. nudifrons $\quad p=0.627, \quad$ L. $\quad$ squamifrons $/ T$. hansoni $p=0.111$, L. nudifrons/T. hansoni $p=0.268$ ), analysis supported model selection with a common slope for all species $(y=0.15705 \times x+b)$. Thus, temperature had a comparable effect on $M_{\mathrm{O}_{2}}$ of all analysed species. Both, the full model with individual, species-specific slopes and the model with a uniform, common slope for all species showed significant differences in oxygen consumption between species (common slope: $p<0.0001$ for all species pairs, species-specific slopes: $p<0.0001$ for all species pairs except $L$. squamifrons/T. hansoni $p=0.0056)$. These can be interpreted as differences in intercept between the regression lines of the different species and thus significant differences in $M_{\mathrm{O}_{2}}$ at the same temperature between all species. Intercepts $(b), y(x=$ habitat temperature) and RMR at habitat temperature are summarised in Table 2. Including the possible outliers in the data set of $L$. squamifrons $\left(5^{\circ} \mathrm{C}\right)$ and L. nudifrons $\left(2{ }^{\circ} \mathrm{C}\right)$ yielded in comparable results (not shown). Raw data and details of analysis are given in Online Resource 1 to 6.

\section{Discussion}

In this study, Antarctic fish species showed differences in oxygen consumption at the same temperature, but no differences in metabolic response to warming. Generally, an

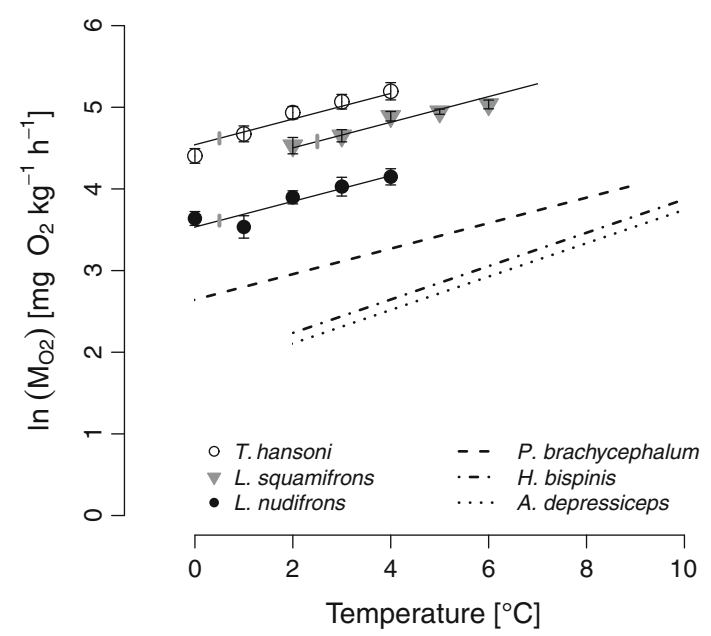

Fig. 1 Natural logarithm of routine metabolic rates in dependence of temperature for the notothenioid species Trematomus hansoni (open circles $n=5$ for all temperatures), Lepidonotothen squamifrons (triangles $n=8$ for $2,3,4{ }^{\circ} \mathrm{C}, n=7$ for $5{ }^{\circ} \mathrm{C}, n=6$ for $6{ }^{\circ} \mathrm{C}$ ) and Lepidonotothen nudifrons (filled circles $n=6$ for $0,1,3,4{ }^{\circ} \mathrm{C}, n=5$ for $2{ }^{\circ} \mathrm{C}$ ). Black error bars indicate standard errors of logarithmic metabolic rates, while grey bars indicate standard errors of the linear model with common slope. Literature data of Pachycara brachycephalum (dashed line) (Van Dijk et al. 1999), Harpagifer bispinis (dotted-dashed line) (Vanella and Calvo 2005) and Austrolycus depressiceps (dotted line) (Vanella and Calvo 2005) are indicated 
Table 2 Routine metabolic rate (RMR) in $\mathrm{mg} \mathrm{O}_{2} \mathrm{~kg}^{-1} \mathrm{~h}^{-1}$ for different fish species at habitat temperature according to the linear model with a common slope for all species $y=0.15705 \times x+b$

\begin{tabular}{lllll}
\hline Species & Intercept & $\begin{array}{l}\text { Habitat } \\
\text { temperature } \\
\left({ }^{\circ} \mathrm{C}\right)\end{array}$ & $\begin{array}{l}y(x=\text { habitat } \\
\text { temp. })\end{array}$ & $\begin{array}{l}\text { RMR at habitat } \\
\text { temperature } \\
\left(\mathrm{mg} \mathrm{O}_{2} \mathrm{~kg}^{-1} \mathrm{~h}^{-1}\right)\end{array}$ \\
\hline Trematomus hansoni & 4.54 & 0 & 4.54 & $83.17 \pm 8.0$ \\
Lepidonotothen squamifrons & 4.19 & 2 & 4.50 & $96.04 \pm 9.5$ \\
Lepidonotothen nudifrons & 3.53 & 0 & 3.53 & $38.67 \pm 3.0$ \\
\hline
\end{tabular}

increase of metabolic rate with increasing temperature complies well with our current understanding of temperature-dependent metabolism (see Clarke and Fraser 2004 and references therein) and is in line with the theory of oxygen limited thermal tolerance (Pörtner 2001). Comparing thermal tolerance of species from different thermal environments within the Southern Ocean, a common slope as response to increasing temperature could be a consequence of evolutionary adaptation to this cold environment with little temperature variation (cf. Table 1) as well as the close evolutionary relationship of these three notothenioid species (Eastman and McCune 2000; Eastman 2005). Moreover, our results indicate significant differences in oxygen consumption at the same temperature. While at $0{ }^{\circ} \mathrm{C}$, highest oxygen consumption rates were found for high-Antarctic T. hansoni, intermediate metabolic rates were found for L. squamifrons with the most northerly distribution in this comparison. Lowest rates were found for $L$. nudifrons from the Antarctic Peninsula region (cf. Table 2).

A higher oxygen consumption of $T$. hansoni compared to $L$. nudifrons matches with the assumption of higher metabolic rates of Antarctic species from high latitudes and a colder environment (Scholander et al. 1953; Wohlschlag 1960; White et al. 2012). As shown in various studies, high-Antarctic species, such as $T$. hansoni, are considered to be highly temperature sensitive, to display a very narrow thermal tolerance window (Pörtner and Farrell 2008; Bilyk and DeVries 2011). In contrast, data of L. squamifrons do not match with this hypothesis, as this species has a northern Antarctic distribution, which would suggest a higher thermal tolerance. However, a study by Beers and Sidell indicated low haematocrit levels to be associated to low critical thermal maxima in Antarctic fish. They found L. squamifrons to show a lower critical thermal maximum and lower haematocrit than two other red-blooded fish (Gobionotothen gibberifrons and Notothenia coriiceps), possibly indicating a relatively low thermal tolerance of this species (Beers and Sidell 2011).

The literature on the effects of acute temperature on rates of oxygen consumption measurements according to a comparable protocol is scarce and only available for the Antarctic eelpout Pachycara brachycephalum (Van Dijk et al. 1999). This species also shows a similar slope of oxygen consumption but a lower oxygen consumption at the same temperature compared to species analysed in this study (Fig. 1). The deep sea origin of the family Zoarcidae suggests lower metabolic rates for the eelpout species compared to species from shelf habitats (Hochachka 1988). Moreover, it supports the finding of high metabolic rates in cold habitats, as shelf waters are usually colder than deep waters. For further comparisons, we added data of Harpagifer bispinis, a plunderfish species, and Austrolycus depressiceps, a Zoarcid, from the Beagle Channel to Fig. 1 (data adjusted to body mass as described in method section). Even though experimental protocols of these species deviate and do include acclimation times, these data support a similar picture (see Vanella and Calvo 2005 for original data and details of experimental protocol). Generally, oxygen consumption seems to be higher in species from cold habitats: The South American eelpout $A$. depressiceps displays lowest oxygen consumption, which is followed by the South American $H$. bispinis, the Antarctic eelpout $P$. brachycephalum, low-Antarctic $L$. nudifrons and high-Antarctic T. hansoni. Differences in oxygen consumption at the same temperature, but a similar response to an increase of temperature could be the basis of differences in thermal windows between species.

Our data suggest that there are general metabolic reaction norms with temperature in benthic cold water fish with an inactive life style, which are reflected in the common slopes of the regressions (Fig. 1). The width of thermal windows is characterised by the y-intercept, the higher the intercept, the smaller the remaining thermal tolerance range into the warmth.

Data on critical thermal limits of the species of this study are only available for species from different regions and thus different thermal environments, complicating direct comparison with our data. While T. hansoni from McMurdo Sound showed a $\mathrm{CT}_{\max }$ of $13.09{ }^{\circ} \mathrm{C}, \mathrm{CT}_{\max }$ values of 15.38 and $15.06{ }^{\circ} \mathrm{C}$ were found for L. squamifrons and $L$. nudifrons from the Western Antarctic Peninsula, respectively (Bilyk and DeVries 2011). While $\mathrm{CT}_{\text {max }}$ data generally bear ecological relevance, they point at somewhat higher capacities to maintain metabolic rates at warm temperatures, when comparing these species. But what might set metabolic limitations in these fish? 
A limiting factor for an increase of metabolic rate might be set, e.g. by the circulatory system as shown by Mark et al. (2002). These authors suggested a cardiovascular capacity limitation to cause a mismatch between oxygen demand and supply at increased temperature in fish. A higher mitochondrial density, as found in Antarctic fish, could enhance capacities of ventilation and circulation (O'Brien and Sidell 2000; Pörtner 2002). (Sub-)cellular space requirements were suggested to constrain maximum scope for activity, as a higher mitochondrial volume is needed in the cold for the same functional capacity as at warmer temperatures (O'Brien and Sidell 2000; Pörtner 2002). In Antarctic fish, metabolic rates are low, but metabolic increments, e.g. due to increasing temperature, are relatively high due to high amounts of enzymes to warrant functional capacities at low temperature, resulting in early capacity limitations (Pörtner et al. 1998; Kawall et al. 2002b; Somero 2004).

Declining width of thermal windows with decreasing habitat temperature variation has been observed for eelpout species from Antarctic and temperate regions (Van Dijk et al. 1999). Beers and Sidell (2011) suggested a positive relation between thermal tolerance and haematocrit levels, which matches well with the oxygen limited thermal tolerance model by Pörtner (2001). This also agrees well with our results of relatively high routine metabolism of $L$. squamifrons for a species with the most northern Antarctic distribution in this study, possibly indicating a low thermal tolerance and a restricted scope for an increase of metabolism. A high performance sensitivity towards increasing temperature was suggested by various studies for species living at the warm-edge of their distributional range (Stillman 2003; Deutsch et al. 2008; Neuheimer et al. 2011), which might also be true for L. squamifrons.

A several-fold higher metabolic rate of polar compared to temperate or tropical ectotherms when extrapolated to the same temperature is hypothesised by the MCA theory (Scholander et al. 1953; Wohlschlag 1960). Since its introduction the MCA concept has been vigorously discussed in the literature. While most studies support higher activity rates for enzymes associated with energy metabolism in species from polar regions (Hochachka 1988; Crockett and Sidell 1990; West et al. 1999; Kawall et al. 2002a) (but also see Magnoni et al. 2013), experimental results deviate widely at the whole-organism level (Holeton 1974; Torres and Somero 1988; Clarke and Johnston 1999; Jordan et al. 2001; Steffensen 2002; White et al. 2012). Our results agree well with a recent analysis by White et al. (2012), who found evidence for MCA at different levels of organisation in fish, with strongest support at the level of whole-animal metabolic rate. However, differences in metabolic rates in our as well as White's study are not even close to a several-fold higher $M_{\mathrm{O}_{2}}$ for species from high latitudes as initially suggested by Scholander et al. (1953) and Wohlschlag (1960). About twofold increased metabolic rates of species from higher latitudes were also considered in papers that actually disagree with the MCA hypothesis (Clarke 1980; cf. Holeton 1974).

Factors usually criticised in experiments supporting MCA, such as the lack of acclimation periods in the experimental protocol and comparison of species of different ecotypes can be excluded in this study. The use of flowthrough respirometers was a major factor criticised by Steffensen (1989, 2002), as this method was supposed to cause overestimation of metabolic rates. Steffensen and coworkers found differences in experimental protocols associated with flow-through respirometry, such as lack of acclimation times, short measuring periods and no consideration of diurnal rhythms, to result in high metabolic rate measurements. However, respiration rates obtained here comply well with values measured for similar species in other studies (Van Dijk et al. 1999; Mark et al. 2002; Steffensen 2005; Brodte et al. 2006; Robinson 2008; Robinson and Davison 2008; Enzor et al. 2013). Moreover, methodological comparison of flow-through versus intermittentflow respirometry showed no significant differences in oxygen consumption data of individual fish measured with both methods according to appropriate protocols (Sandersfeld and Knust unpublished). As in many other studies on high-Antarctic fish (Axelsson et al. 1992; Davison 2001; Maffia et al. 2001), T. hansoni was not kept at its usual habitat temperature of below $-1{ }^{\circ} \mathrm{C}$ in this study. Although an elevation of metabolic rate due to higher holding temperature cannot be excluded, a comparison of literature data makes it seem unlikely (Robinson 2008).

There are various factors possibly influencing metabolic rates, which cannot be completely controlled. While seasonal impacts on shelf water temperature expand only into the upper 100-200 m of the water column (Clarke 1988; Barnes et al. 2006), seasonal impacts on metabolic rates have been reported with respect to spawning as well as food availability in fish (Beamish 1964; Karås 1990). As weight and size measurements suggest fish of this study to be adults (cf. Kock and Kellermann 1991; T. Sandersfeld unpublished data) and experiments were conducted after the spawning season (cf. Table 1), metabolic rates are likely to have been on a lower level. Moreover, various physiological and ecological as well as habitat-specific factors are known to possibly influence metabolic rates (Post 1990; Campbell et al. 2009; Giesing et al. 2011; Ohlberger et al. 2012). However, only the parameters of lifestyle and activity could be considered and were regarded to be comparable for the analysed species.

There are various attempts to explain high metabolic rates in Antarctic fish. The mitochondrial proton leak 
makes up a significant part of an organism's metabolic rate. Hardewig et al. (1999) estimated the proton leak to make up for about $10 \%$ of respiration in liver mitochondria of the Antarctic L. nudifrons. This makes a higher wholeanimal metabolic rate in Antarctic fish with higher mitochondrial densities probable. While this is supported by results from studies on enzyme levels (e.g. Crockett and Sidell 1990) and matches with observations of low growth in polar ectotherms (DeVries and Eastman 1981; La Mesa and Vacchi 2001; Pörtner et al. 2005), results of wholeorganism metabolic rates are controversial. Studies at lower organismic levels are often less complex and yield clearer results. Nevertheless, when aiming to transfer results from lower levels to ecosystems, one can hardly get around taking the whole-organism level into account (cf. Barnes and Peck 2008). It is questionable, whether measurements of metabolic rate via oxygen consumption are the optimal tools to estimate routine metabolic costs, as it includes a variety of complex processes (see also Clarke 1991). However, alternatives are scarce. As routine metabolism makes up for about $50 \%$ of Antarctic fish energy expenditure (Brodte et al. 2006), differences in routine metabolic costs are likely to have fitness consequences (cf. Pörtner and Knust 2007). High-Antarctic fish were shown to grow slower compared to species from the seasonal pack-ice zone (La Mesa and Vacchi 2001). While low growth performance is suggested to be linked to lifestyle and food resources (La Mesa and Vacchi 2001), it could also suggest limitations in energy allocation of highAntarctic species: High routine metabolic costs could limit energy investment into growth (cf. Donelson and Munday 2012), which is crucial for a species abundance and population structure. Regarding metabolic stressors, such as rising water temperatures and ocean acidification, which can additionally increase metabolic rates, generally elevated metabolic costs could be disadvantageous.

\section{Conclusion}

Regarding regional thermal variability, habitat conditions did not affect acute thermal tolerance patterns in the studied species. Our results suggest that metabolic responses to rising temperature of species from Antarctic Regions do not differ, but that species from high latitudes start off at higher metabolic rates. Increasing habitat temperature, even on small scales of some $0.1^{\circ} \mathrm{C}$ as suggested for the habitats of species studied here, are likely to increase routine metabolic costs. Recent models suggest that warm deep water entering the Filchner Trough in the Southern Weddell Sea can lead to temperature increases of up to $2{ }^{\circ} \mathrm{C}$ (Hellmer et al. 2012). For high-latitude species with high routine metabolic rates and low-growth performance, increasing habitat temperatures might further skew this imbalance affecting growth and reproduction and thereby population structures. In consequence, the discussion about higher or lower metabolic rates of polar fish species could be crucial for our understanding of thermal sensitivity of these animals in the current stage of climate change.

Acknowledgments The authors would like to thank Nils Koschnick and Timo Hirse for technical assistance during experiments, Fredy Véliz Moraleda for animal care, the crew of RV Polarstern for valuable field support during ANT-XXVII/3 and ANT-XXVIII/4 as well as Christian Bock for helpful advice on experimental work and Stephan Frickenhaus for statistical support. Moreover, we thank three anonymous reviewers for their constructive comments that helped to significantly improve the manuscript. This study was supported by Polarstern Grant No. AWI_PS77-03 and AWI_PS79-04. Tina Sandersfeld was partly supported by a Ph.D. scholarship of the Helmholtz Graduate School for Polar and Marine Research and by the PACES II programme.

Compliance with ethical standards All applicable international, national and/or institutional guidelines for the care and use of animals were followed. This research was conducted in accordance with the ethics and guidelines of the German law. The experiments have been approved by the veterinary inspection office (Senatorin für Bildung. Wissenschaft und Gesundheit, Bremen, Germany) under the Permit Number AZ: 522-27-11/02-00 (93) issued on 15th January 2008 and valid until 14th January 2013.

Conflict of interest We disclose no conflict of interest in regard to this research.

Open Access This article is distributed under the terms of the Creative Commons Attribution 4.0 International License (http://creative commons.org/licenses/by/4.0/), which permits unrestricted use, distribution, and reproduction in any medium, provided you give appropriate credit to the original author(s) and the source, provide a link to the Creative Commons license, and indicate if changes were made.

\section{References}

Andriashev A (1986) Zoarcidae. In: Whitehead EA (ed) Fishes of the north-eastern Atlantic and the Mediterranean, vol 3. UNESCO, Paris, pp 1130-1150

Axelsson M, Davison W, Forster M, Farrell A (1992) Cardiovascular responses of the red-blooded antarctic fishes Pagothenia bernacchii and P. borchgrevinki. J Exp Biol 167:179-201

Barnes DK, Peck LS (2008) Vulnerability of Antarctic shelf biodiversity to predicted regional warming. Clim Res 37:149-163

Barnes DK, Fuentes V, Clarke A, Schloss IR, Wallace MI (2006) Spatial and temporal variation in shallow seawater temperatures around Antarctica. Deep-Sea Res Pt II 53:853-865

Beamish FWH (1964) Seasonal changes in the standard rate of oxygen consumption of fishes. Can J Zool 42:189-194

Beers JM, Sidell BD (2011) Thermal tolerance of Antarctic notothenioid fishes correlates with level of circulating hemoglobin. Physiol Biochem Zool 84:353-362

Bilyk KT, DeVries AL (2010) Freezing avoidance of the Antarctic icefishes (Channichthyidae) across thermal gradients in the Southern Ocean. Polar Biol 33:203-213 
Bilyk KT, DeVries AL (2011) Heat tolerance and its plasticity in Antarctic fishes. Comp Biochem Physiol A 158:382-390. doi:10. 1016/j.cbpa.2010.12.010

Boyce SJ, Clarke A (1997) Effect of body size and ration on specific dynamic action in the Antarctic plunderfish, Harpagifer antarcticus Nybelin 1947. Physiol Biochem Zool 70:679-690

Brodte E, Knust R, Pörtner HO (2006) Temperature-dependent energy allocation to growth in Antarctic and boreal eelpout (Zoarcidae). Polar Biol 30:95-107. doi:10.1007/s00300-0060165-y

Campbell H, Davison W, Fraser K, Peck L, Egginton S (2009) Heart rate and ventilation in Antarctic fishes are largely determined by ecotype. J Fish Biol 74:535-552

Chown SL, Jumbam KR, Sorensen JG, Terblanche JS (2009) Phenotypic variance, plasticity and heritability estimates of critical thermal limits depend on methodological context. Funct Ecol 23:133-140. doi:10.1111/j.1365-2435.2008.01481.x

Clark TD, Sandblom E, Jutfelt F (2013) Aerobic scope measurements of fishes in an era of climate change: respirometry, relevance and recommendations. J Exp Biol 216:2771-2782. doi:10.1242/jeb. 084251

Clarke A (1980) A reappraisal of the concept of metabolic cold adaptation in polar marine invertebrates. Biol J Linn Soc 14:77-92. doi:10.1111/j.1095-8312.1980.tb00099.x

Clarke A (1988) Seasonality in the Antarctic marine environment. Comp Biochem Physiol B 90:461-473

Clarke A (1991) What is cold adaptation and how should we measure it? Am Zool 31:81-92

Clarke A, Fraser K (2004) Why does metabolism scale with temperature? Funct Ecol 18:243-251

Clarke A, Johnston NM (1999) Scaling of metabolic rate with body mass and temperature in teleost fish. J Anim Ecol 68:893-905. doi:10.1046/j.1365-2656.1999.00337.x

Clarke A, Griffiths HJ, Barnes DK, Meredith MP, Grant SM (2009) Spatial variation in seabed temperatures in the Southern Ocean: implications for benthic ecology and biogeography. J Geophys Res-Biogeo 114:G03003

Coppes Petricorena ZL, Somero GN (2007) Biochemical adaptations of notothenioid fishes: comparisons between cold temperate South American and New Zealand species and Antarctic species. Comp Biochem Physiol A 147:799-807

Crockett EL, Sidell BD (1990) Some pathways of energy metabolism are cold adapted in Antarctic fishes. Physiol Zool 63:472-488

Davison W (2001) Respiration of the emerald rockcod, a notothenioid fish from Antarctica. New Zealand Natural Sciences 26:13-20

Deutsch CA, Tewksbury JJ, Huey RB, Sheldon KS, Ghalambor CK, Haak DC, Martin PR (2008) Impacts of climate warming on terrestrial ectotherms across latitude. Proc Natl Acad Sci USA 105:6668-6672

DeVries AL, Eastman JT (1981) Physiology and ecology of notothenioid fishes of the Ross Sea. J R Soc N Zeal 11:329-340

Donelson JM, Munday PL (2012) Thermal sensitivity does not determine acclimation capacity for a tropical reef fish. J Anim Ecol 81:1126-1131

Eastman JT (2005) The nature of the diversity of Antarctic fishes. Polar Biol 28:93-107

Eastman J, McCune A (2000) Fishes on the Antarctic continental shelf: evolution of amarine species flock? J Fish Biol 57:84-102

Enzor LA, Zippay ML, Place SP (2013) High latitude fish in a high $\mathrm{CO}_{2}$ world: synergistic effects of elevated temperature and carbon dioxide on the metabolic rates of Antarctic notothenioids. Comp Biochem Physiol A 164:154-161. doi:10.1016/j.cbpa. 2012.07.016

Giesing ER, Suski CD, Warner RE, Bell AM (2011) Female sticklebacks transfer information via eggs: effects of maternal experience with predators on offspring. Proc R Soc Lond B 278:1753-1759

Gon O, Heemstra PC (1990) Fishes of the Southern Ocean, vol 1. JLB Smith Institute of Ichthyology, Grahamstown

Hardewig I, Peck L, Pörtner H (1999) Thermal sensitivity of mitochondrial function in the Antarctic Notothenioid Lepidonotothen nudifrons. J Comp Physiol B 169:597-604

Hellmer HH, Kauker F, Timmermann R, Determann J, Rae J (2012) Twenty-first-century warming of a large Antarctic ice-shelf cavity by a redirected coastal current. Nature 485:225-228. doi:10.1038/nature11064

Hochachka P (1988) Channels and pumps-determinants of metabolic cold adaptation strategies. Comp Biochem Physiol B 90:515-519

Holeton GF (1974) Metabolic cold adaptation of polar fish: Fact or artefact? Physiol Zool 47:137-152

Hunt BM, Hoefling K, Cheng CHC (2003) Annual warming episodes in seawater temperatures in McMurdo Sound in relationship to endogenous ice in notothenioid fish. Antarct Sci 15:333-338

Hureau JC (1994) The significance of fish in the marine Antarctic ecosystems. Polar Biol 14:307-313

Jobling M (1994) Fish bioenergetics. Fish and Fisheries Series, vol 13. Chapman \& Hall, London

Johnston IA, Clarke A, Ward P (1991) Temperature and metabolic rate in sedentary fish from the Antarctic, North Sea and IndoWest Pacific Ocean. Mar Biol 109:191-195

Jordan AD, Jungersen M, Steffensen J (2001) Oxygen consumption of East Siberian cod: no support for the metabolic cold adaptation theory. J Fish Biol 59:818-823

Karå P (1990) Seasonal changes in growth and standard metabolic rate of juvenile perch, Perca fluviatilis L. J Fish Biol 37:913-920. doi:10.1111/j.1095-8649.1990.tb03595.x

Kawall H, Torres J, Sidell B, Somero G (2002a) Metabolic cold adaptation in Antarctic fishes: evidence from enzymatic activities of brain. Mar Biol 140:279-286. doi:10.1007/s002270100695

Kawall HG, Torres JJ, Sidell BD, Somero GN (2002b) Metabolic cold adaptation in Antarctic fishes: evidence from enzymatic activities of brain. Mar Biol 140:279-286. doi:10.1007/s002270100695

Killen SS, Costa I, Brown JA, Gamperl AK (2007) Little left in the tank: metabolic scaling in marine teleosts and its implications for aerobic scope. Proc R Soc Lond B 274:431-438

Kock K-H, Kellermann A (1991) Reproduction in Antarctic notothenioid fish. Antarct Sci 3:125-150

Koehn RK, Shumway SE (1982) A genetic/physiological explanation for differential growth rate among individuals of the American oyster Crassostrea virginica (Gmelin). Mar Biol Lett 3:35-42

La Mesa M, Vacchi M (2001) Review. Age and growth of high Antarctic notothenioid fish. Antarct Sci 13:227-235

Lannig G, Bock C, Sartoris FJ, Pörtner HO (2004) Oxygen limitation of thermal tolerance in cod, Gadus morhua L., studied by magnetic resonance imaging and on-line venous oxygen monitoring. Am J Physiol Regul Integr Comp Physiol 287:R902R910

Locarnini RA, Mishonov AV, Antonov JI, Boyer TP, Garcia HE (2010) World Ocean Atlas 2009. In: Levitus S (ed), NOAA Atlas NESDIS 69, vol 1, U.S. Government Printing Office, Washington DC

Maffia M, Rizzello A, Acierno R, Rollo M, Chiloiro R, Storelli C (2001) Carbonic anhydrase activity in tissues of the icefish Chionodraco hamatus and of the red-blooded teleosts Trematomus bernacchii and Anguilla anguilla. J Exp Biol 204:3983-3992

Magnoni LJ, Scarlato NA, Ojeda FP, Wohler OC (2013) Gluconeogenic pathway does not display metabolic cold adaptation in liver of Antarctic notothenioid fish. Polar Biol 36:661-671. doi:10.1007/s00300-013-1292-x 
Mark FC, Bock C, Pörtner HO (2002) Oxygen-limited thermal tolerance in Antarctic fish investigated by MRI and P-31-MRS. Am J Physiol Regul Integr Comp Physiol 283:R1254-R1262. doi:10.1152/ajpregu.00167.2002

Meredith MP, King JC (2005) Rapid climate change in the ocean west of the Antarctic Peninsula during the second half of the 20th century. Geophys Res Lett 32:L19604

Neuheimer A, Thresher R, Lyle J, Semmens J (2011) Tolerance limit for fish growth exceeded by warming waters. Nat Clim Change $1: 110-113$

Norin T, Malte H, Clark TD (2014) Aerobic scope does not predict the performance of a tropical eurythermal fish at elevated temperatures. J Exp Biol 217:244-251. doi:10.1242/jeb.089755

O'Brien KM, Sidell BD (2000) The interplay among cardiac ultrastructure, metabolism and the expression of oxygen-binding proteins in Antarctic fishes. J Exp Biol 203:1287-1297

Ohlberger J, Mehner T, Staaks G, Hölker F (2012) Intraspecific temperature dependence of the scaling of metabolic rate with body mass in fishes and its ecological implications. Oikos 121:245-251. doi:10.1111/j.1600-0706.2011.19882.x

Olbers D, Gouretski V, Seiß G, Schröter J (1992) Hydrographic Atlas of the Southern Ocean. Alfred Wegener Institute for Polar and Marine Research, Bremerhaven, Germany, 17 pages, 82 plates, hdl:10013/epic. 12913

Pörtner HO (2001) Climate change and temperature-dependent biogeography: oxygen limitation of thermal tolerance in animals. Naturwissenschaften 88:137-146

Pörtner HO (2002) Climate variations and the physiological basis of temperature dependent biogeography: systemic to molecular hierarchy of thermal tolerance in animals. Comp Biochem Physiol A 132:739-761

Pörtner HO (2012) Integrating climate-related stressor effects on marine organisms: unifying principles linking molecule to ecosystem-level changes. Mar Ecol Prog Ser 470:273-290. doi:10.3354/Meps 10123

Pörtner HO, Farrell AP (2008) Physiology and climate change. Science 322:690-692. doi:10.1126/science. 1163156

Pörtner HO, Knust R (2007) Climate change affects marine fishes through the oxygen limitation of thermal tolerance. Science 315:95-97

Pörtner HO, Hardewig I, Sartoris FJ, Van Dijk PLM (1998) Energetic aspects of cold adaptation: critical temperatures in metabolic, ionic and acid-base regulation. In: Pörtner HO, Playle RC (eds) Cold ocean physiology. Cambridge University Press, Cambridge, pp $88-120$

Pörtner HO, Mark FC, Bock C (2004) Oxygen limited thermal tolerance in fish? Answers obtained by nuclear magnetic resonance techniques. Resp Physiol Neurobiol 141:243-260. doi:10.1016/j.resp.2004.03.011

Pörtner HO, Storch D, Heilmayer O (2005) Constraints and trade-offs in climate-dependent adaptation: energy budgets and growth in a latitudinal cline. Sci Mar 69:271-285

Post JR (1990) Metabolic allometry of larval and juvenile yellow perch (Perca flavescens): in situ estimates and bioenergetic models. Can J Fish Aqua Sci 47:554-560

R Core Team (2015) R: A language and environment for statistical computing, 3.2.2 edn. R Foundation for Statistical Computing, Vienna

Rijnsdorp AD, Peck MA, Engelhard GH, Möllmann C, Pinnegar JK (2009) Resolving the effect of climate change on fish populations. ICES J Mar Sci 66:1570-1583

Robinson E (2008) Antarctic fish: thermal specialists or adaptable generalists? Ph.D. thesis, University of Canterbury, Christchurch
Robinson E, Davison W (2008) The Antarctic notothenioid fish Pagothenia borchgrevinki is thermally flexible: acclimation changes oxygen consumption. Polar Biol 31:317-326. doi:10. 1007/s00300-007-0361-4

Schlitzer R (2011) Ocean Data View, 4.5.0 edn., http://odv.awi.de, 2012

Scholander P, Flagg W, Walters V, Irving L (1953) Climatic adaptation in arctic and tropical poikilotherms. Physiol Zool 26:67-92

Sil'yanova ZS (1982) Oogenesis and maturity stages of fishes of the family Nototheniidae. J Ichthyol 22:81-89

Somero GN (2004) Adaptation of enzymes to temperature: searching for basic "strategies". Comp Biochem Physiol B 139:321-333

Somero GN, DeVries AL (1967) Temperature tolerance of some Antarctic fishes. Science 156:257-258

Steffensen JF (1989) Some errors in respirometry of aquatic breathers: how to avoid and correct for them. Fish Physiol Biochem 6:49-59

Steffensen JF (2002) Metabolic cold adaptation of polar fish based on measurements of aerobic oxygen consumption: Fact or artefact? Artefact! Comp Biochem Physiol A 132:789-795. doi:10.1016/ s1095-6433(02)00048-x

Steffensen JF (2005) Respiratory systems and metabolic rates. In: Farrell AP, Steffensen JF (eds) The physiology of polar fishes, fish physiology, vol 22. Academic Press, San Diego, pp 203-238. doi:10.1016/S1546-5098(04)22005-2

Stillman JH (2003) Acclimation capacity underlies susceptibility to climate change. Science 301:65. doi:10.1126/science.1083073

Strobel A, Bennecke S, Leo E, Mintenbeck K, Pörtner HO, Mark FC (2012) Metabolic shifts in the Antarctic fish Notothenia rossii in response to rising temperature and $\mathrm{PCO}_{2}$. Front Zool 9:28

Torres JJ, Somero GN (1988) Metabolism, enzymic activities and cold adaptation in Antarctic mesopelagic fishes. Mar Biol 98: 169-180. doi:10.1007/bf00391192

Turner J et al (2014) Antarctic climate change and the environment: an update. Polar Rec 50:237-259

Van Dijk PLM, Tesch C, Hardewig I, Pörtner HO (1999) Physiological disturbances at critically high temperatures: a comparison between stenothermal Antarctic and eurythermal temperate eelpouts (Zoarcidae). J Exp Biol 202:3611-3621

Vanella FA, Calvo J (2005) Influence of temperature, habitat and body mass on routine metabolic rates of Subantarctic teleosts. Sci Mar 69(Supp. 2):317-323

West JL, Bailey JR, Almeida-Val VMF, Val AL, Sidell BD, Driedzic WR (1999) Activity levels of enzymes of energy metabolism in heart and red muscle are higher in north-temperate-zone than in Amazonian teleosts. Can J Zool 77:690-696. doi:10.1139/z99016

White CR, Alton LA, Frappell PB (2012) Metabolic cold adaptation in fishes occurs at the level of whole animal, mitochondria and enzyme. Proc R Soc Lond B 279:1740-1747. doi:10.1098/rspb. 2011.2060

Whitehouse M, Meredith M, Rothery P, Atkinson A, Ward P, Korb R (2008) Rapid warming of the ocean around South Georgia, Southern Ocean, during the 20th century: forcings, characteristics and implications for lower trophic levels. Deep-Sea Res PtI 55:1218-1228

Wieser W (1994) Cost of growth in cells and organisms: general rules and comparative aspects. Biol Rev 69:1-33

Wohlschlag DE (1960) Metabolism of an antarctic fish and the phenomenon of cold adaptation. Ecology 41:287-292. doi:10. $2307 / 1930217$ 